\title{
Haiguo Tuzhi and Chinese Impressions on Turkey in the Late Qing Dynasty
}

\author{
JIANG Xinyu \\ Northwest University, Xi'an, China
}

\begin{abstract}
Haiguo Tuzhi (Illustrated Treatise on the Maritime Kingdoms) is one of the earliest gazetteers in early modern China. In order to change the Chinese view of the outside world, scholar-official Wei Yuan (1794-1857) and his contemporaries compiled this gazetteer in the middle of the 19th century. Haiguo Tuzhi contains numerous geographical, historical, and political details covering both the western and eastern hemispheres, which derived from the known information on Western researches and Chinese ancient texts from the Tang Dynasty (618-907) to Ming Dynasty (1368-1644). Haiguo Tuzhi is a significant work in China, which affected the modernization movement around East Asia, such as Meiji Restoration in Japan. There are two juan, or scrolls concerning Turkey (the Ottoman Empire), called southern Duluji (Turkey) and northern Tuluji (Turkey), in Haiguo Tuzhi’s “Southwest Ocean” part and "Great West Ocean” part covering the origin of Turkish state, the geographical location and circumstance of Turkey, the distribution of ethnic groups throughout this country, the relationship between Turkey and European countries, the religious situation, and the policies carried out by Turkish monarchs. Although Haguo Tuzhi is a panoramic opus which focuses on the whole outline of countries, it also documents plenty details about Turkish clothing, dietary habits, and characters of people. Haguo Tuzhi provides a chance to learn the Chinese impressions on Turkish state and people in 19th century.
\end{abstract}

Keywords: Haiguo Tuzhi, Wei Yuan, Turkey

China and Turkey (the Ottoman Empire) had contacts during the Ming dynasty. In 1544, Suleiman the Magnificent sent a mission to China. According to the History of Ming, Turkish (called Lumi in this book) diplomatic missions have visited China for five times. In addition, a large number of Turkish merchants came to China along the Silk Road for trade. At that time, most Chinese people know little about the situation in Turkey, and they are not interested in understanding the outside world. For a long time, most Chinese thought that China was located in the center of the world, and they focus solely on the situation in their country and neighboring countries. Because, at the time, Chinese believe that China can develop without the foreign resources, and in history, most invasions of China came from the surrounding ethnic groups. In the Qing period, government has implemented the policy of Self-isolation for long terms. This policy limited the Chinese understanding of the outside world. Before the First Opium War (the First Anglo-Chinese War, 1840-1842), Chinese thought people from the outside world are all the barbarians, and various strange creatures live in there. In 1840, Britain invaded China; however, the Daoguang Emperor didn't even know the distance between the United Kingdom and China, and how many countries between the UK and his empire. When analyzing the

JIANG Xinyu, postgraduate student, Institute of Middle Eastern Studies, Northwest University, Xi’an, China. 
important reasons for the failure of the Opium War, many Chinese officials realized that the lack of understanding of the world, including Britain, is a fatal weakness for the empire. Therefore, Wei Yuan and other intellectuals began to explore the situation in various countries of the world, of which Turkey is one of the focuses of their attention.

\section{Wei Yuan and Haiguo Tuzhi}

Wei Yuan was born in Shaoyang, Hunan Province in 1794. He is the son of the local landowner. When he was young, he attended the imperial examinations and became an official of the Qing Dynasty. Wei Yuan is a typical Chinese scholar-official in that time. He was very familiar with Chinese traditional books and histories, such as the Classic of Poetry ${ }^{1}$, the Book of History ${ }^{2}$. Different from most Chinese scholar-officials, however, Wei Yuan especially accepted a theory of Confucian classics that advocates change (Liu, 2015, p. 23). This ideology asserted that "the destiny" is not static, and the old dynasty was replaced by a new one with the change of "the destiny". Wei Yuan was deeply influenced by this thought. He said that "before several generations, the heaven, earth, people, and other things were different from contemporary ones". He proposed that "Has the flow direction of the 'Chi' ${ }^{3}$ changed during the Ming Dynasty (1368-1644)? Has it flowed along the earth from west to east?” In addition, Wei Yuan likes reading the Buddhist scriptures. According to some Buddhist scriptures (such as Agama), there are four continents in the world and China is located in one of them. Therefore, China is not at the center of the world. In a manner of speaking, the ancient Chinese classics and sutras make Wei Yuan have different views of the world from other people in the same time, and help him understand the world.

The direct cause of Wei Yuan's creation of the Haiguo Tuzhi was the First Opium War (the First Sino-British War) which took place in 1840. In this war, British used modern weapons and tactics, defeating the numerous Qing Dynasty's troops by a small and professional army in the mainland of China, repeatedly bombard China's major cities and the United Kingdom coerced Chinese government to sign the "Treaty of Nanking”. At the time, many Chinese officials considered China was the strongest country in the world, feeling shame of the fact that this great empire was defeated by an army from a small island. During the First Opium War, Wei Yuan had a further understanding of the world by interrogating the British prisoners, writing an essay called Record to England. In June 1841, Wei Yuan met with Lin Zexu who was the chief commander of the Qing Dynasty's army during the war and was banished to Ili region in Xinjiang because of the failure. In order to enable the Qing government to understand the situation of world and help the government formulate policies to protect China from foreign countries invasion (Liu, 2015, p. 28), Lin Zexu passed his draft manuscript, a gazetteer called Sizhou Zhi, to Wei Yuan, and hoped that Wei Yuan could create a comprehensive gazetteer based on this. On the basis of reference to foreign records and ancient Chinese books, a few months later, Wei Yuan and his contemporaries completed the task given to him by Lin Zexu. They compiled a gazetteer called Haiguo Tuzhi (Illustrated Treatise on the Maritime Kingdoms) in $1842^{4}$.

\footnotetext{
1 A book contains the oldest chronologically authenticated Chinese poems.

${ }^{2}$ It is a collection of rhetorical prose attributed to figures of ancient China.

${ }^{3}$ Chi in Chinese medicine and other fields refers to the formation of the human body and the basic energy of life-sustaining activities.

4 Reorganized in 1847-1848, and 1852.
} 


\section{Turkey in the Haiguo Tuzhi}

In spite of obtaining modern geographical information from foreign countries and some complete maps of the world drew in the 19th century by Western, but Wei Yuan was still skeptical about Western geographical view. He believed in the correctness of the Buddhist scriptures and Chinese ancient books; he argued that "Buddhist classics divide the earth into four continents, the continents recorded in the Western Map are just two of them, and they forcefully divide the two continents into five or four...” (Wei, 2010, p. 1847). He said, "[In fact,] Asia, Europe, and Libya [refer to Africa] are Jambudvipa continent; North and South America are Aparagodaniya continent” (Wei, 2010, p. 1849). Therefore, according to the location relative to China, Wei Yuan divided the world by his own standards, rather than by the Western standards (not by continent, but by ocean), into six parts, respectively, Southeast Ocean (including Southeast Asia, Korea, Japan, and Oceania), Southwest Ocean (including South Asia, Arabia, and Asia Minor), Great West Ocean (Europe), Small West Ocean (Africa), North Ocean (including states around Arctic ocean coast), and Outer Great West Ocean (including South and North America) (Wei, 2010, p. 1). Because of Turkish (Ottoman Empire's), a country spread-eagles Southwest Ocean and on Great West Ocean. Wei Yuan recorded Turkey in two volumes, called South Duluji (South Turkey) and North Tuluji (North Turkey) in this book.

In Haiguo Tuzhi, there are no officially-unified name for this country, so the terms Duluji (都鲁机) (mainly used in Southwest Ocean scrolls), Tuluji (土鲁机) (mainly used in Great West Ocean scrolls), Tuerqi (土尔其), and Tuerqi (土耳其) (used today) were mainly used by Wei Yuan and his companions, to refer broadly to Turkey. He described the scope of North and South Turkey and subdivided the specific areas of two region. Wei Yuan said, "South Turkey is at the westernmost region of Asia, also known as Asia Minor, Persia is in its east, bounded by the Tigris, Mediterranean Sea in the west, and Arabia in the south, ... the Black Sea in the north” (Wei, 2010, pp. 887-888). "North Turkey borders Greece and the Aegean Sea to the south, Russia and Austria to the north, the Black Sea and Marmara Sea to the east... Austria to the northwest” (Wei, 2010, p. 1371).

He believed that South Turkey includes Anatolia, Caramania, Adana, Maras, Sivas, Trabzon, Armenia, Kurdistan, Mesopotamia (include present-day Iraq and Kuwait), and Syria (includes present-day Syria, Lebanon, Palestine, and Israel). The southern border of this country is on the coast of the Dead Sea (see details in Figure 1 and 2). Wei Yuan didn't record that Ottoman Empire have territories in Arabian Peninsula and Africa. In Haiguo Tuzhi, Egypt was considered as an independent country. On the other hand, North Turkey includes the Balkan countries, and today's European part of Turkey, specifically including Croatia, Albania, Serbia, Bulgaria, Rumelia, Moloda, Vara Valahia (see details in Figure 3). Wei Yuan learned that Greece and other places have been independent from Ottoman, "Greece... was once occupied by Turkey, but is now independent and has become a state itself” (Wei, 2010, p. 1383). But at the same time, he also believes that Hungary is a part of Turkey, he said "Hungary, now is incorporated into North Turkey” (Wei, 2010, p. 1370). 


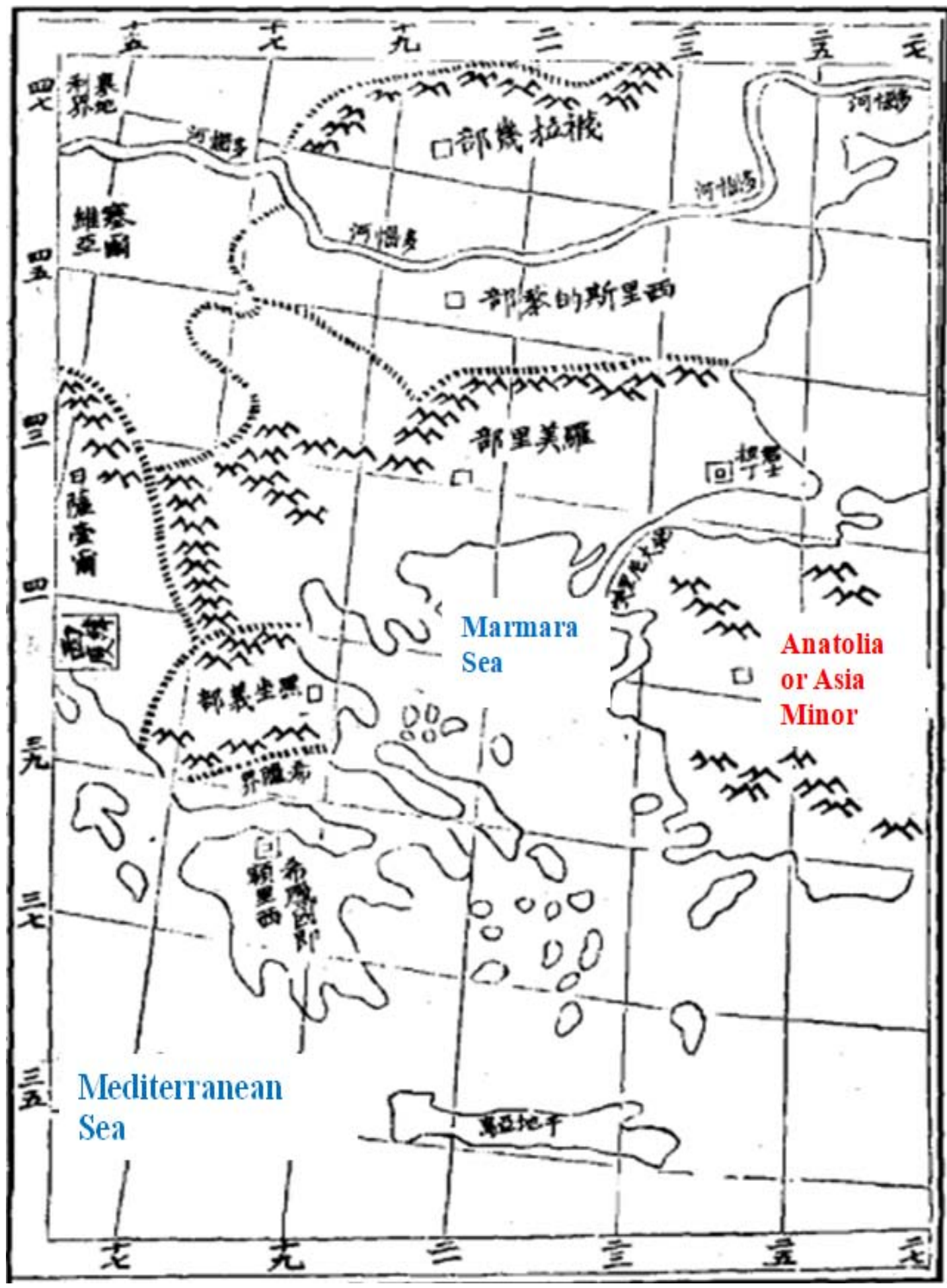

Figure 1. South Turkey. 


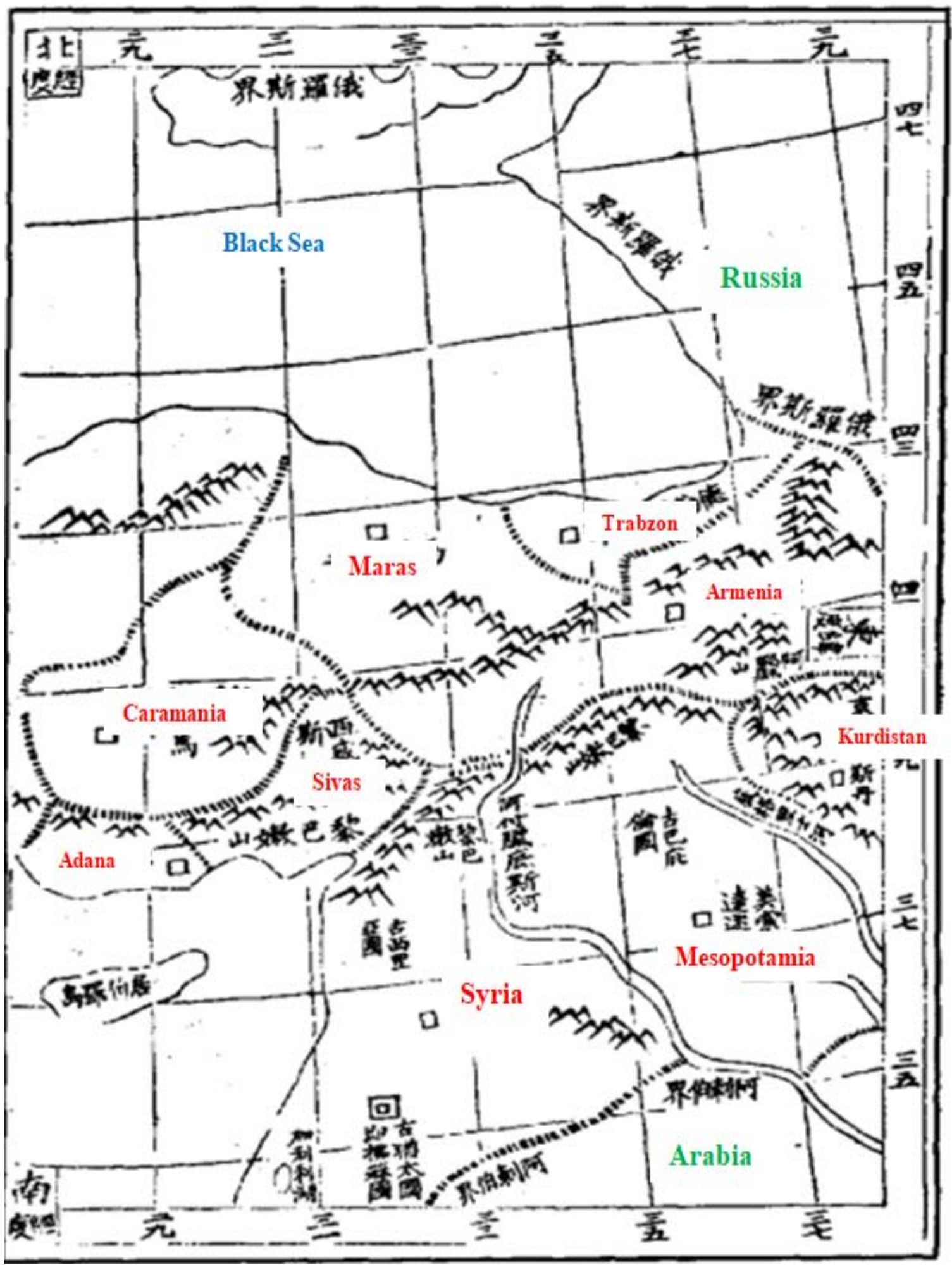

Figure 2. South Turkey. 


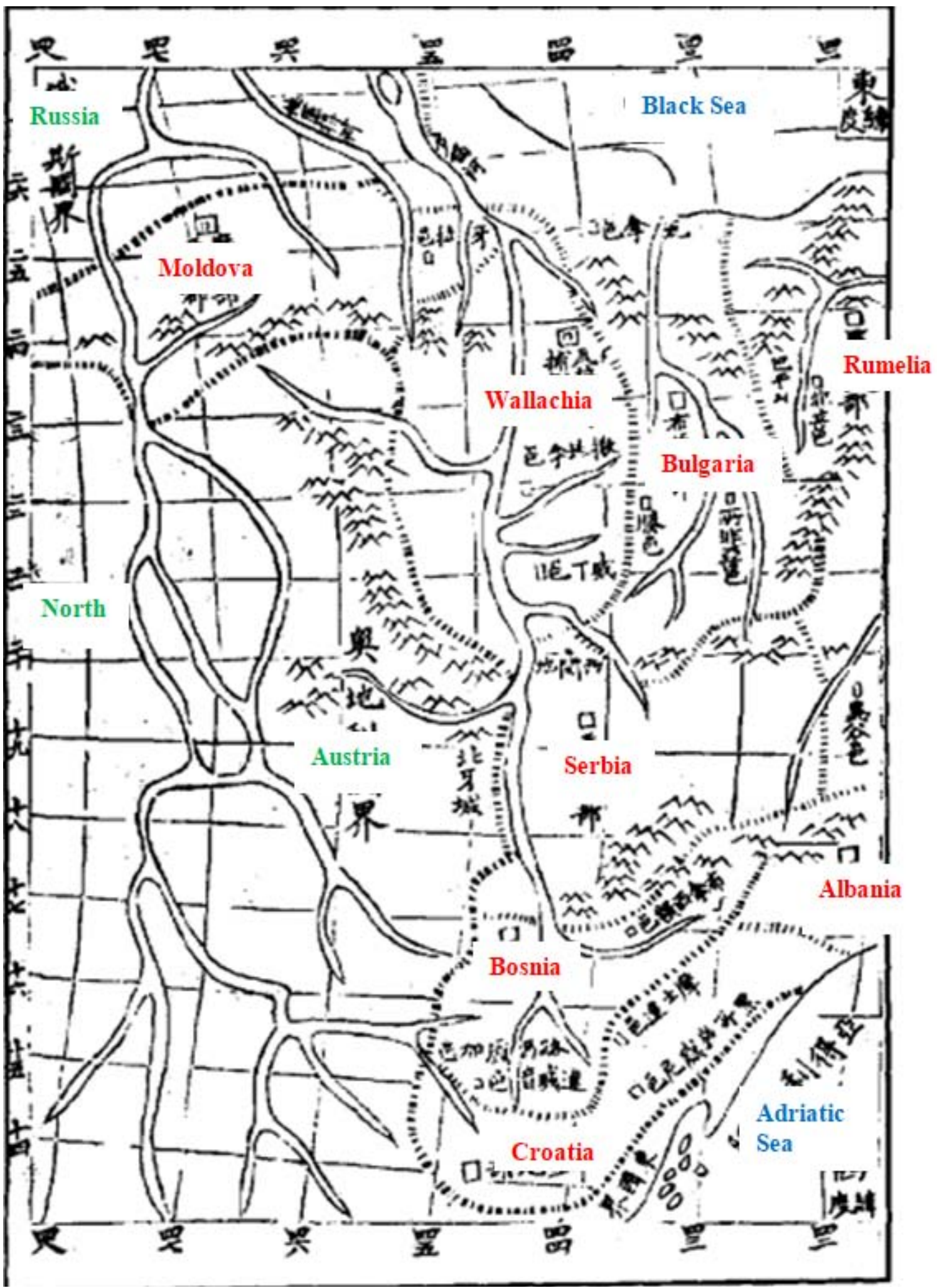

Figure 3. North Turkey. 


\section{History}

Haiguo Tuzhi introduced Turkish history from four perspectives at least. First, the book shows the history of various countries that have appeared on this land, such as the history of Greece, Rome Empire, Jewish, and Babylonian countries. He advocated that "The Asian part of this country is called South Turkey. This land is vast and very fertile. In ancient times, countries such as Babylonia, Armenia, Lydia, and Judea were built in this land” (Wei, 2010, p. 883). And then, he began to describe the history of these countries. Second, he described the rise and expansion of Islam. He had known that the rise of the Ottoman state is part of the history of Islam. Third, he learned that the Turks originated in Central Asia (Wei, 2010, p. 1361). Wei Yuan wrote that "South Turkish people originally belonged to the Tatars. They were nomadic in ancient time, and live in the Pamirs and Ili. And later, they migrated westward to Asia Minor...” (Wei, 2010, p. 892). And then he recorded the history from Seljuk to Ottoman (Wei, 2010, p. 1361). Fourth, Wei Yuan hopes to explore the history of the "West Women's Kingdom" which was recorded in ancient Chinese books. In the New Book of Tang, there was a record of this state: "In the west of Fu-lin ${ }^{5}$, there is a West Women's Kingdom, and all people in this country are women. This country has many wonderful treasures...” (Wei, 2010, p. 890). Tongkao ${ }^{6}$ said,

West Women's Kingdom lies to the west of Pamirs Plateau. The country's customs are the same as those of the East Women's Kingdom (East Women's Kingdom was in the southeast of the Pamirs, near the Tibetan Empire and destroyed by later). The West Women's Kingdom is attached to the Fu-lin and began tribute to China in the Eighth Year of Zhen Guan period (635) in Tang Dynasty. (Wei, 2010, p. 890)

And Kunyu Tushuo ${ }^{7}$ said, “a women country called Amazon lied to the west of many Tatars' countries, [people in this country are] brave and battlewise... now it was occupied by other country". Wei Yuan cited the above materials in Haiguo Tuzhi and he made specific mention of the country occupied the West Women's Kingdom which is Turkey (Wei, 2010, p. 890). In other words, he believed that West Women's Kingdom was existed from at least the Tang Dynasty to the rise of Turkey.

\section{Politics}

Wei Yuan used materials about the Turkish monarch and bureaucracy. First of all, he thought in Turkey, the monarch has autocratic power. He said,

Turkey's political system is different from other countries in Europe. Political power is concentrated in the hands of the monarch. People should obey his orders and cannot raise objections. The king is called the shadow of God... and the king is considered to rule the country by the will of God. (Wei, 2010, p. 1363)

In addition, the monarch is a religious leader. "In this country, people remember the virtues of Osman I. Therefore, ... the descendants of Osman I are still selected as Islamic leaders of this country” (Wei, 2010, p. 1363). For the bureaucratic system, Haiguo Tuzhi said,

Grand Vizier, who is responsible for checking the quality of goods in cities... Reis Effendi, managing the internal affairs and diplomacy, Tefterdar Effendi managing the treasury, Tehelebi Effendi, managing the navy, Pasha, managing the army, Mollahs, managing Islamic affairs and education; Mufti, managing laws, ... and Ulema, managing documents. (Wei, 2010, pp. 1363-1364)

Besides, Wei Yuan has learned about the relatively new situations in Turkey, for example, the country has

\footnotetext{
5 "Fu-lin" is adopted to refer to Byzantium since Tang Dynasty.

${ }^{6}$ Literally: “Comprehensive Examination of Literature”. The book written by Ma Duanlin in 1317.

7 The book written by a Ferdinand Verbiest, a priest of the Society of Jesus, in 1674.
} 
had a hard time in controlling its own local officials,

It is very difficult to [Turkish monarch] to abolish betrayal Pasha. This work was completed around 1810, Eighth Year of Jia Qing, however, the newly appointed Pasha was rebelled again after a few years. ... Egypt as its vassal state. Pasha was originally appointed to rule this land. Now [Egypt Pasha] not only does not obey the monarch's order, but it has occupied Turkey’s Syrian region. (Wei, 2010, p. 885)

In addition, Wei Yuan learned that Turkey is facing an extremely serious environment. In diplomacy, although it was protected by the United Kingdom and France, these two countries are only for the purpose of against Russia. He quoted Xu Jiyu as saying that

Europeans do not like Islam and hate the tyranny of the Turkish King. British and French do not like Turkey. They help Turkish just because they were worried about Tsarist Russia will annex Turkey. Because of geography, the Tsarist Russian army is not good at fighting on the oceans. If Turkey is occupied, Russia will have the opportunity to develop the Navy and may challenge the hegemony of British and French. (Wei, 2010, p. 1382)

\section{Customs}

On the research of Turkey, Wei Yuan mostly pay attention to the customs, such as dress, dietary habit, filial piety, and marriage. He said,

[Turkish] Clothes and decorations are very similar to the Oriental countries. The clothes and sleeves are loose and different from European styles. People take off their shoes before entering the house. They sat on the ground and eat with their hand. The woman should practice purdah and cannot meet other males... The country prohibits alcohol. People are willing to build hotels for travelers and give in charity to others. They smoke opium. ... They respect their parents and unity brothers. Legacy can only be inherited by their children and brothers, and others cannot profit from it. Before marriage, [they] discuss the issue of bride price, and then discuss the date of marriage, and the number of wives and concubines. The children of concubines are equal to those of his wife. If the wife is infertile, the law allows her husband to abandon her... (Wei, 2010, p. 1365)

\section{Ethnic Groups and Religions}

Wei Yuan learned that Turkey is an Islamic country, but not all citizens are Muslims, and importantly, Muslim is not one race. He said, “Turkey is the only Islamic country in Europe” (Wei, 2010, p. 1361). "Every Turkish believes in Islam, and the king is their religious leader...” (Wei, 2010, p. 1365), "There are other ethnic live in Turkey with about two million population... The Greeks live near the harbor... about a million people, they believe in Christianity, or religion preached by Rome Pope", "The Arabs live in the eastern part of the country and there are more than one million people. Some of them are nomadic and believe in Islam” (Wei, 2010, p. 896). In addition, Haiguo Tuzhi also records the culture and customs of the some ethnic groups in Turkey.

There are three ethnic groups in this country, Greeks, Jews, and people whose hats are triangular (tricorne), of which the Greeks account for half of them. Jews suffer from discrimination and engage in pasta manufacturing. The people wearing triangle hat are clever and thrifty. They do business in the country, rarely trade with foreigners. The Greeks are clever, eloquent and good at business ... their ate simply, only vegetable, olives and candy. (Wei, 2010, pp. 1365-1366)

\section{Rivers, Mountains, and Properties}

In Haiguo Tuzhi, at least the names of the 38 rivers in Turkey were recorded, mainly located in the North Turkey. The descriptions to the mountains were presented in the introductions of each specific areas. The Haiguo Tuzhi also contains an overall introduction of the production of Turkey. 
Turkish produces cotton, cotton grown in Europe can earn 3.5 million tael of silver every year... also produces tobacco, and some places can produce 200,000 packs of cigarettes. People smoke. Turkey sells grape juice... and ships 100,000 dan ${ }^{8}$ per year. About 4,000 boxes of opium are sold from Turkey to China. Turkey also produces medicinal herbs, wax, silk and fine wool. Turkish horses are tall and good at running. Few manufactured goods are produced in domestic, buying products from abroad. This country has many harbor. (Wei, 2010, pp. 896-897)

In addition, when introducing the situation of each place, the product status of each area was also recorded.

\section{Legends and Stories}

In Haiguo Tuzhi, many myths are recorded. For example, the tales of the reborn phoenix and a magical river, when a sheep drank the water of this river, the color of the wool on it will change from black to white. These legends may come from ancient Chinese books and rumors of foreigners. Different from other people in his contemporaries, Wei Yuan believes in the authenticity of the records of ancient books, such as his historical records of the West Women's Kingdom, while, Xu Jiyu, an equally famous enlightened scholar in that time, argued that the tales of the West Women's Kingdom is ridiculous (Xu, 2001, p. 168).

\section{Conclusion}

Chinese ancient books rarely documenting the situation in Turkey and most of content are myths and legends, such as the phoenix and the West Women's Kingdom. Wei Yuan also adopted these legends in his writings, but these stories just have a bit space in this book. In general, he showed a real Turkey for Chinese, most of the book Haiguo Tuzhi is about the objective situation in Turkey. Although Wei Yuan's introduction of the Ottoman Empire was sketchy, Haiguo Tuzhi is indeed a comprehensive gazetteer. The descriptions of Turkey's overall history, politics, ethnic groups, and the natural environment are relatively detailed, and most of them are accurate.

In Haiguo Tuzhi, the scene of the decline of the Ottoman Empire was displayed to the Chinese. Wei Yuan also analyzed the reasons for the decline of the country because the Turkish monarch was a tyrant and the people only studied old knowledge and didn’t learn from the West, “They only read the scriptures and didn’t study science. They ridiculed foreign-made telescopes, microscopes, measuring instruments, and watches, saying these were clever tricks and wicked craft. They did not accept the European calendar..." Most of the content mentioned by Wei Yuan also existed in China at that time, so he may wish to warn Chinese with the case of Ottomans.

However, Wei Yuan hasn't get information about Ottoman was undergoing reforms, the Tanzimat. He received new messages from the West, most of which were negative news about Turkey and Islam. Until the end of the 19th century and the beginning of the 20th century, some Chinese scholars began to visit Turkey and knew the more real facts of Turkey and the Middle East. Despite all this, the Haiguo Tuzhi played an enlightening role. In the 19th and early 20th centuries, many Chinese (including some scholars in other East Asia countries, such as Korea and Japan) learned about the world through this book. In general, Haiguo Tuzhi takes the crucial step for Chinese to understand Turkey.

\section{References}

Liu, Y. (2015). A study of Haiguo Tuzhi (Ph. D. diss., University of Yangzhou).

Wei, Y. (2010). Haiguo Tuzhi. Changsha: Yuelu Shushe Press.

Xu, J. Y. (2001). A short account of the maritime circuit. Shanghai: Shanghai Bookstore Publishing House.

\footnotetext{
81 dan almost equal to $50 \mathrm{~kg}$.
} 